\title{
Vegetation of a 25-Year Exclosure on the Edwards Plateau, Texas
}

\author{
FRED E. SMEINS, TERRY W. TAYLOR, AND LEO B. \\ MERRILL
}

Highlight: An evaluation was made of current species composition, production and 25-year vegetation trends within an exclosure on the Texas $A \& M$ University Agricultural Research Station at Sonora, Texas. Community composition was variable and most species responded individually to soil variables, particularly soil depth and degree and kind of stoniness. Common curlymesquite (Hilaria belangeri) was the most characteristic and widespread species of the area. communities dominated by Texas cupgrass /Eriochlod sericea), on soils greater than $25 \mathrm{~cm}$ in depth, produced 4,330, 2,235 , and $504 \mathrm{~kg} / \mathrm{ha}$ in June and August 1972 and January 1973, respectively. Wright threeawn (Aristida wrightii) dominated communities with soil depths of $15 \mathrm{~cm}$, produced $1,318,1,349$, and $413 \mathrm{~kg} / \mathrm{ha}$ for the same dates; and hairy tridens (Erioneuron pilosum) sites with soil depths of $10 \mathrm{~cm}$ yiclded $970,1,156$, and $84 \mathrm{~kg} / \mathrm{ha}$. Vegetation change over the past 2.5 years has been primarily adjustment in relative dominance of species rather than addition or loss of species. Following establishment of the exclosure some species adiusted to previous grazing history, and thereafter primary changes followed precipitation variation.

Relict areas and historical documents are sources commonly used to ascertain the pre-settlement vegetation of an area (Clements, 1934; Larsen and Whitman, 1942; Dyksterhuis, 1958). Use of the relict concept, however, requires qualifications of specific climatic, edaphic, pyric, and biotic factors. Unless these factors are clearly defined, status

Authors are associate professor, Kange Science Department, and graduate research assistant, Soil and Crop Science Department, Texas A\&M Unjuersity, College Station 77843; and professor, Texas A\&M University, Agricultural Research Station, Sonora 76955.

The study was approved by the director, Texas Agr. Exp. Sta. as TA-11344.

Manuscript received July 26,1974. of the vegetation may be subject to misinterpretations. For example, ecosystems known to have been influenced by large grazing animals and fire in the past are questionable representatives of the original vegetation if these factors are removed (Larsen, 1940; Daubenmire, 1968; Mason, 1970; Beetle, 1974).

Often native vegetation is significantly altered by man's activities before a detailed documentation is made of its characteristics. In these cases an alternative to the relict method is to establish exclosures which are protected against influences such as grazing and fire. Two major problems exist with interpretations of exclosures. Firstly, protection, as with relict areas, does not necessarily represent natural or optimum conditions. Secondly, an area once subjected to change by man may not, upon protection, revert to its original state. Kind, degree, and duration of the disturbance may profoundly affect vegetation changes that occur upon protection.

This investigation was designed to quantitatively evaluate the vegetation of a 25-year-old (established 1948) 16-ha livestock and deer exclosure on the Edwards Plateau, Texas. Specific objectives of the study were: (1) to determine herbaceous species composition and scasonal production for selected communities within the exclosure; (2) to relate plant distribution and abundance to edaphic variables; and (3) to construct patterns of vegetation change from records of the past 25 years.

\section{Study Area and Methods}

The Sonora Research Station is located 56 kilometers south of Sonora, Tex., at an elevation of approximately $735 \mathrm{~m}$. It is within the Edwards Plateau Resource Area of Texas (Godfrey et al., 1970). Average annual rainfall for 44 years at the Station is $55.7 \mathrm{~cm}$, with peaks in May and September. Summers are hot with an average July temperature of $28.5^{\circ} \mathrm{C}$, and winters are mild with an average Janaury temperature of 
$9.0^{\circ} \mathrm{C}$ (U.S. Dep. Commerce, 1926-1970). The growing season averages 235 days.

The exclosure occurs in an area with a long history of heavy continuous grazing prior to 1948 , but since then no grazing by large animals has occurred; small mammals have not been excluded. It has been protected against fire since 1948 and for many years prior to 1948 . Soils are Tarrant stony and silty clays with slopes 0 to $8 \%$ (Soil Conserv. Serv., 1968). Vegetation has changed significantly under the impact of confined grazing pressure by domestic livestock and elimination of fires (Bray, 1906). Prior to 1900, up to 125 animal units per section grazed the study area (Youngblood and Cox, 1922) while from 1900 to 1948 approximately 70 animal units per section was common (Merrill, 1959). Early documents describe the area as grassland with scattered woody plants along drainages and on steep, rocky slopes (Havard, 1885; Bentley, 1898; Buechner, 1944). Today woody plants are a major component of the vegetation.

Within the exclosure 16 stands were delineated based on visual homogeneity of vegetation, topography, and soil. They varied in size from 0.1 to 1.0 ha. Thirty quadrats $(50 \mathrm{~cm} \mathrm{X}$ $100 \mathrm{~cm}$ ) were located across each stand in a stratified random systcm. The canopy-coverage method was used to describe herbaceous and woody plant species composition (Daubenmire, 1959). Frequency values also were determined for each species in each stand.

Seasonal green herbagc and mulch (standing dead, fresh, and humic) weights were determined for three stands selected to represent low, medium, and high herbage production. Five randomly placed quadrats $(50 \mathrm{~cm} \times 100 \mathrm{~cm})$ were clipped at ground level with hand shears in each stand, dried for 24 hours at $80^{\circ} \mathrm{C}$, and weighed. Samples were collected on June 26 , 1972, August 28, 1972, and January 26, 1973.

Vegetation surveys have been conducted annually or biannually on the exclosure for the past 25 years. Thirty-six permanent, regularly spaced square-foot quadrats $(30.5 \mathrm{~cm} X$ $30.5 \mathrm{~cm}$ ) were established in 1948 and basal diameter of species measured. Records for the years 1948, 1953, 1958, 1963 , and 1968 were used to show long-term vegetation change.

Soil depth and degree of surface stoniness were measured in each stand. Soil was probed with a calibrated metal rod at eight locations in a grid fashion in each of the 30 quadrats and an average depth calculated for each stand. Rock cover for each quadrat was determined following the same procedure used for plant cover. Rock size for each quadrat fell into one of four classes based on diameter: $5 \mathrm{~cm}$ or less, $6-15 \mathrm{~cm}$, 16-50 $\mathrm{cm}$, and unbroken bedrock slabs. Soil texture of the surface $0-10 \mathrm{~cm}$ was determined for each stand (Buoyoucos, 1962).

The Bray and Curtis (1957) ordination technique was used to identify community structure and species-environmental interrelationships. This technique involved determination of degree of similarity for stand pairs and arrangement of stands in a single or multi-axis system on the basis of differences in degree of similarity. The stands were arrayed along a single derived axis in such a manner as to illustrate their degree of similarity. To relate species behavior and environmental factors to the derived ordination axis, the axis was arbitrarily divided into four equal-sized categories with 2, 8, 4, and 2 stands, respectively (Table 1).

\section{Results and Discussion}

\section{Species-Environmental Relationships}

A total of 157 taxa were sampled: 110 forbs, 28 grasses, and 19 woody species. Taxonomic nomenclature follows Gould (1969). Most species had an average absolute foliar cover of $1 \%$ or less across all stands. Approximately 24 species collectively accounted for $70 \%$ of the foliar cover values of the total vegetation (Table 1 ).

Twelve grass, forb, and woody species were plotted against the derived ordination gradient and most showed a normal distribution pattern (Fig. 1). Most other species have similar patterns (Table 1), but each species responded independently to the gradient. There seemed to be no grouping of species into coherent community combinations.

To further test for interspecific relationships and associations, correlation coefficients were calculated for all possible species combinations taken two at a time across all quadrats for which a species had a cover value. Interspecific correlations were rare. Less than $2 \%$ of all possible correlations gave significant values. Two grasses, Halls panicum (Panicum hallii) and cane bluestem (Bothriochloa barbinodis var. barbinodis) gave a positive 0.57 correlation $(p<0.05)$. Two forbs, plains dozedaisy (Aphanostephus ramossissimus) and Lindheimer copperleaf (Acalypha lindheimeri), showed a positive $0.54(p<0.05)$ correlation. Texas wintergrass (Stipa

Table 1. Average percent absolute foliar cover (AC) and average percent absolute frequency (F) for selected woody species, grasses, and forbs within categories of the derived ordination gradient.

\begin{tabular}{|c|c|c|c|c|c|c|c|c|}
\hline \multirow[b]{3}{*}{ Species } & \multicolumn{8}{|c|}{ Category and number of stands } \\
\hline & \multicolumn{2}{|c|}{$1(2)$} & \multicolumn{2}{|c|}{$2(8)$} & \multicolumn{2}{|c|}{$3(4)$} & \multicolumn{2}{|c|}{$4(2)$} \\
\hline & $\mathrm{AC}$ & $\mathrm{F}$ & $\mathrm{AC}$ & $\mathrm{F}$ & $\mathrm{AC}$ & $\mathrm{F}$ & $\mathrm{AC}$ & $\mathrm{F}$ \\
\hline \multicolumn{9}{|l|}{ Woody } \\
\hline Elbowbush & - & - & 2.3 & 9 & 0.2 & 2 & 1.9 & 7 \\
\hline Ashe juniper & - & - & 9.4 & 25 & 1.4 & 5 & 0.9 & 7 \\
\hline Honey mesquite & 1.7 & 5 & 1.0 & 10 & 1.9 & 5 & 0.5 & 3 \\
\hline Vasey shin oak & 1.1 & 24 & 2.5 & 21 & 1.0 & 4 & 0.1 & 5 \\
\hline \multicolumn{9}{|l|}{ Grasses } \\
\hline Wright threeawn & - & - & 4.1 & 33 & 10.2 & 52 & 11.5 & 78 \\
\hline Cane bluestem & 1.0 & 17 & 2.8 & 17 & 1.1 & 9 & 1.2 & 17 \\
\hline Sideoats grama & 6.1 & 12 & 4.9 & 25 & 5.7 & 43 & 2.6 & 18 \\
\hline Hairy grama & - & - & - & - & 1.0 & 13 & 5.5 & 52 \\
\hline Texas cupgrass & 44.0 & 65 & 11.9 & 30 & - & - & 1.2 & 5 \\
\hline Hairy tridens & - & - & 1.0 & 9 & 3.0 & 36 & 35.2 & 95 \\
\hline Common & & & & & & & & \\
\hline $\begin{array}{l}\text { curlymesquite } \\
\text { Green }\end{array}$ & 28.3 & 73 & 9.5 & 42 & 5.3 & 37 & 6.5 & 47 \\
\hline sprangletop & - & - & 2.1 & 10 & - & - & 0.1 & 10 \\
\hline Fall witchgrass & 0.6 & 9 & 0.4 & 17 & 1.2 & 45 & 1.6 & 43 \\
\hline Halls panicum & 0.1 & 7 & 0.7 & 20 & 2.2 & 38 & 0.6 & 17 \\
\hline $\begin{array}{l}\text { Texas winter- } \\
\text { grass }\end{array}$ & 1.6 & 42 & 4.6 & 42 & 0.6 & 10 & 1.2 & 7 \\
\hline \multicolumn{9}{|l|}{ Forbs } \\
\hline Lind heimer & & & & & & & & \\
\hline copperleaf & - & $-\overline{1}$ & 0.9 & 21 & -.1 & 1 & 0.1 & 12 \\
\hline Plains dozedaisy & 0.9 & 28 & 1.1 & 36 & 3.4 & 48 & 0.1 & 9 \\
\hline Velvet bundle- & & & & & & & & \\
\hline $\begin{array}{l}\text { flower } \\
\text { Indian blanket }\end{array}$ & - & - & 0.7 & & & 3 & 1.1 & $\begin{array}{r}47 \\
4\end{array}$ \\
\hline Indian blanket & 14.2 & 65 & 2.4 & 14 & .1 & 3 & 0.1 & $\begin{array}{r}4 \\
34\end{array}$ \\
\hline $\begin{array}{l}\text { Pincushion daisy } \\
\text { Texas blue- }\end{array}$ & $y \quad 0.2$ & 17 & 0.2 & 15 & 0.1 & 7 & 1.0 & 34 \\
\hline $\begin{array}{l}\text { Texas blue- } \\
\text { bonnet }\end{array}$ & 2.9 & 60 & 0.6 & 16 & 0.6 & 11 & 0.6 & 17 \\
\hline $\begin{array}{l}\text { Upright prairie- } \\
\text { coneflower }\end{array}$ & 0.5 & 45 & 0.5 & 38 & 0.5 & 13 & 0.7 & 15 \\
\hline $\begin{array}{l}\text { Drummond } \\
\text { skullcap }\end{array}$ & 0.3 & 25 & 0.3 & 21 & 0.6 & 43 & 1.0 & 74 \\
\hline Resurrection & & & & & & & & \\
\hline plant & - & - & 0.7 & 5 & 9.0 & 47 & - & - \\
\hline $\begin{array}{l}\text { Herbaceous cover } \\
\quad(\%)\end{array}$ & 111.7 & & 66.0 & & $71.1 \mathrm{~b}$ & & $87.9 \mathrm{~b}$ & \\
\hline Woody cover $(\%)$ & $5.0 \mathrm{t}$ & & 34.5 & & $7.8 \mathrm{t}$ & & $4.1 \mathrm{~b}$ & \\
\hline
\end{tabular}

*Values followed by the same letter in the same row are not different at the 0.05 level of significance. 

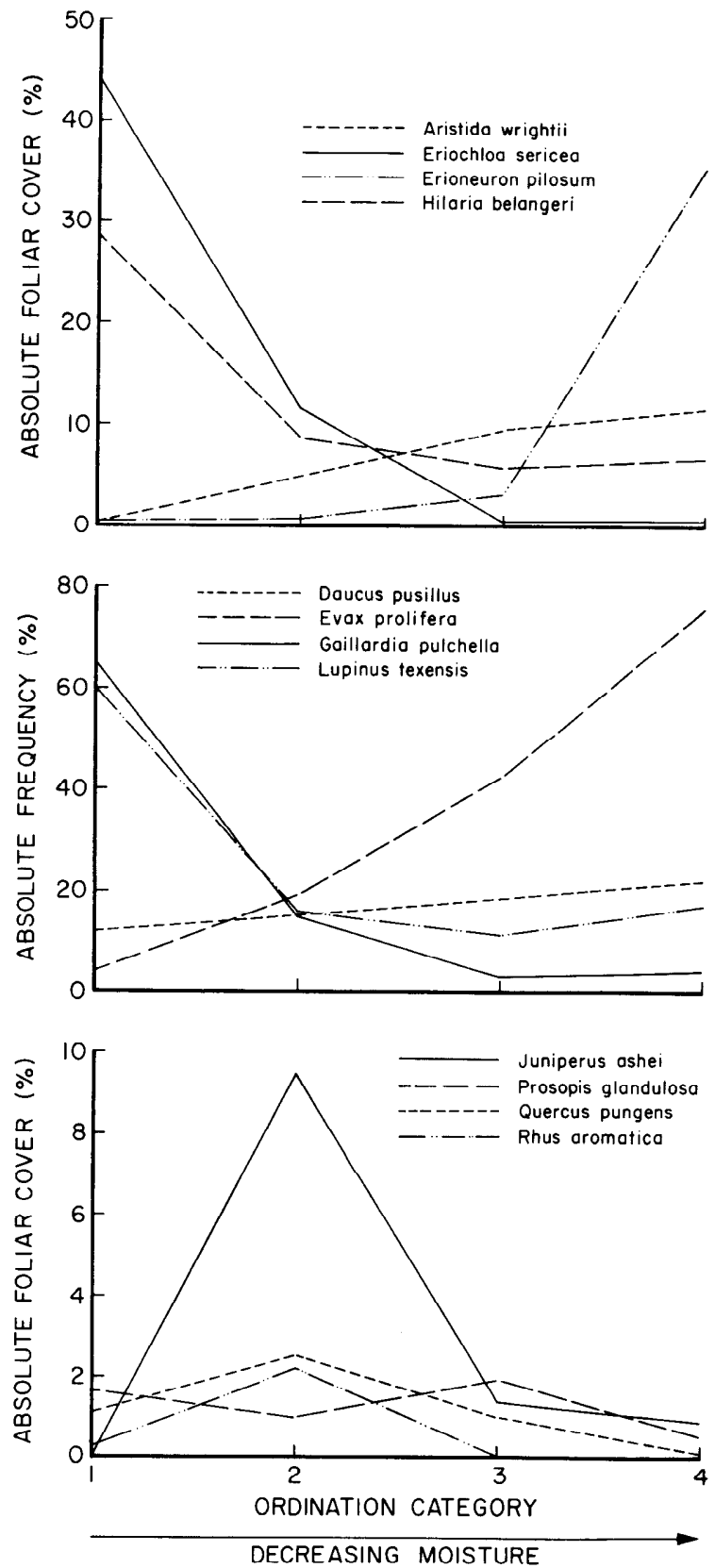

Fig. 1. Average absolute foliar cover or absolute frequency for 12 species plotted against 4 categories of the derived ordination gradient.

leucotricha) had a positive correlation of $0.64(p<0.05)$ with elbowbush (Forestiera pubescens var. pubescens).

To test for relationships with soil characteristics, various measured soil parameters were plotted against the derived gradient. Two factors showed significant correlations, soil depth $(r=-0.69, p<0.01)$ and rock index $(+0.69, p<0.01)$ (Fig. 2). Soil texture showed little variation from stand to stand and was not correlated with the gradient. The rock index was calculated by multiplying rock cover class numbers by the rock size class numbers. The index gave increasing value to situations reflecting both greater cover and size; values rangeu from 1 to $28(1 \times 1$ to $7 \times 4)$.

The left-hand portion of the gradient (Fig. 1 and 2) is represented by deep soils (average $27 \mathrm{~cm}$ ) and low rock index (7). Texas cupgrass and Texas wintergrass were characteristic of these conditions. As soils became shallower and rock index increased these species were progressively replaced by Wright threeawn, sideoats grama (Bouteloua curtipendula var. curtipendula), and Halls panicum. On the shallow and rocky sites, hairy tridens (Erioneuron pilosum) and hairy grama (Bouteloua hirsuta) were common species. Common curlymesquite was the most ubiquitous species in the study. It had an overall average absolute cover of $10.4 \%$ across all stands and occurred in 218 of 480 (43\%) quadrats.

Categories 3 and 4 of the gradient (Fig. 2) had similar soil depth and rock indices. The factor that distinguished the two categories was presencc of an almost continuous, unfractured bedrock under category 4 stands while categories 1,2 , and 3 were underlain by fractured limestone and thus had more potential water storage (Albertson, 1937).

Awnless bushsunflower (Simsia calva), velvet bundleflower (Desmanthus velutinus), and orange zexmenia (Zexmenia hispida) were common forbs on deep soils, with a progression toward Indian mallow (Abutilon incanum) and Lindheimer copperleaf on intermediate depths $(14 \mathrm{~cm})$. On the most xeric sites, Plantago spp., Erodium spp., Bighead evax (Evax prolifera), pincushion daisy (Gaillardia suavis), and Drummond scullcap (Scutellaria drummondii) were common. Indian blanket (Gaillardia pulchella) and Texas bluebonnet (Lupinus texensis) are examples of forbs that were relatively abundant in all stands but showed greatest absolute frequency on the more mesic sites. Upright prairie-coneflower (Ratibida columnifera) occurred throughout the area, while resurrection plant (Selaginella lepidophylla) was found primarily around the margin of rock outcrops within shallow soil areas.

Woody species covered approximately $20 \%$ of the area sampled (Table 1). Stands in category 2 had generally higher cover particularly of Ashe juniper (Juniperus ashei). Stands in this category typically had numerous boulder outcrops and deep rock fissures, which permitted deep rootings of these woody species.

In arid and semiarid environments moisture is considered a major limiting factor to plant ecesis, distribution, and abundance (Albertson, 1937; Dix, 1960; Nicholson and Hulett, 1969). Results of this study agree. Increased soil depth and consequent increased soil volume, which provided greater moisture storage, exerted the major influence on the vegetation pattern and production. Hulett et al. (1969) found similar relationships in limestone grasslands of Kansas.

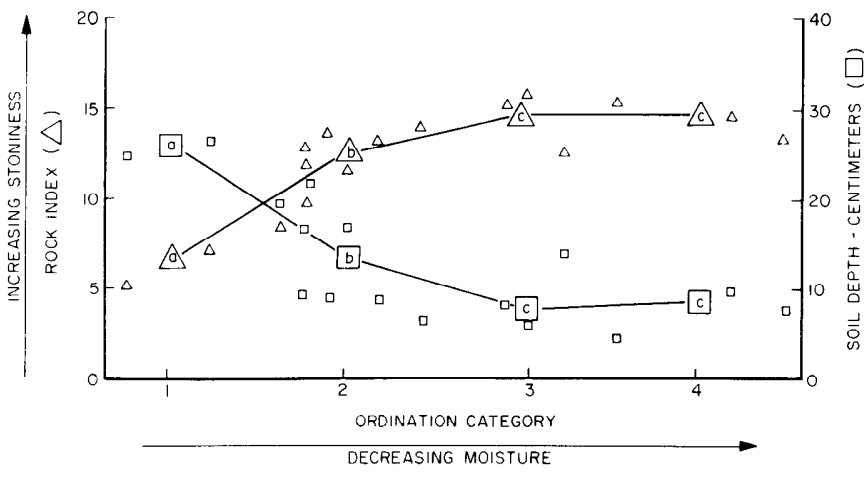

Fig. 2. Soil depth and rock index for 16 stands and averaged for 4 categories along the derived ordination gradient. Large symbols containing the same letter on the same line are not different at the 0.05 level of significance. 
Table 2. Green herbage production ( $\mathrm{kg} / \mathrm{ha}$ ) and standing dead, fresh, and humic mulch (kg/ha) for 3 stands at 3 times during 1972-73.

\begin{tabular}{ccc}
\hline Stand and date & $\begin{array}{c}\text { Green } \\
\text { herbage }\end{array}$ & Mulch \\
\hline Eriochloa sericea & & \\
June 26, 1972 & $4,330 \mathrm{a}^{*}$ & $6,246 \mathrm{a}$ \\
Aug. 28, 1972 & $2,235 \mathrm{~b}$ & $5,774 \mathrm{ab}$ \\
Jan. 26, 1973 & $504 \mathrm{~cd}$ & $4,472 \mathrm{~b}$ \\
Aristida wrightii & & \\
June 26,1972 & $1,318 \mathrm{c}$ & $2,752 \mathrm{c}$ \\
Aug. 28, 1972 & $1,349 \mathrm{c}$ & $2,238 \mathrm{~cd}$ \\
Jan. 26, 1973 & $413 \mathrm{~d}$ & $1,732 \mathrm{~cd}$ \\
Erioneuron pilosum & & \\
June 26, 1972 & $970 \mathrm{c}$ & $734 \mathrm{~d}$ \\
Aug. 28, 1972 & $1,456 \mathrm{c}$ & $936 \mathrm{~d}$ \\
Jan. 26, 1973 & $84 \mathrm{~d}$ & $546 \mathrm{~d}$ \\
\hline
\end{tabular}

*Values followed by the same letter in the same column are not at the 0.05 level of significance.

\section{Production}

Three stands were qualitatively selected on the basis of apparent high, medium, and low production (Fig. 3). The Texas cupgrass stand produced the greatest total live matter in June $(4,330 \mathrm{~kg} / \mathrm{ha})$ and declined at later sampling dates (Table 2; Fig. 3). Texas cupgrass dominated the stand completely with $95 \%$ of total live production in June. Common curlymesquite contributed about one-fourth of the green matter in August as the cupgrass became dormant. In January Texas wintergrass and a variety of forbs provided only 504 $\mathrm{kg} / \mathrm{ha}$ green biomass. Production greatly exceeded other sites; however, this community represents less than $2 \%$ of the total area. This stand had an average soil depth of $27 \mathrm{~cm}$, the soil texture was loam, it occurred in a topographically low area along a drainage, and the underlying limestone had many fractures.

The stand dominated by Wright threeawn had a production of $1,349 \mathrm{~kg} / \mathrm{ha}$ in August, which was only slightly higher than the June clipping. January production was $413 \mathrm{~kg} / \mathrm{ha}$ (Table 2). The site was characterized by a heterogeneous composition (Fig. 3). Wright threeawn contributed 36 and $42 \%$ of the biomass in June and August but yielded no green matter in January. Other grasses with production values of greater than $50 \mathrm{~kg} / \mathrm{ha}$ at any clipping were sideoats grama, hairy grama, Texas cupgrass, and common curlymesquite. The loam soil averaged $12 \mathrm{~cm}$ over a fractured limestone.

The most xeric stand, with hairy tridens as dominant, produced nearly $1,000 \mathrm{~kg} / \mathrm{ha}$ by late June and increased to $1,456 \mathrm{~kg} /$ ha by late August. Late summer growth of hairy grama made the greatest contribution to the increase (Fig. 3). January production was low and consisted of a few scattered forbs. The silty loam soil averaged $8 \mathrm{~cm}$ and was underlain by a nearly continuous limestone slab.

Ovcrall, late summer green matter production was somewhat higher than expected. This is probably related to a rather unusual precipitation pattern for 1972. The area would normally receive approximately $33 \mathrm{~cm}$ of precipitation through August. In 1972 nearly $50 \mathrm{~cm}$ had fallen by the 15th of August and $30 \mathrm{~cm}$ of this amount fell between August 1 and August 15. This, of course, provided ideal moisture conditions, and thus production values obtained on August 28 may be considered higher than normal.

Total standing dead, fresh, and humic mulch values ranged from $6,246 \mathrm{~kg} / \mathrm{ha}$ in early summer on the Texas cupgrass stand to $546 \mathrm{~kg} / \mathrm{ha}$ in midwinter on the hairy tridens stand (Table

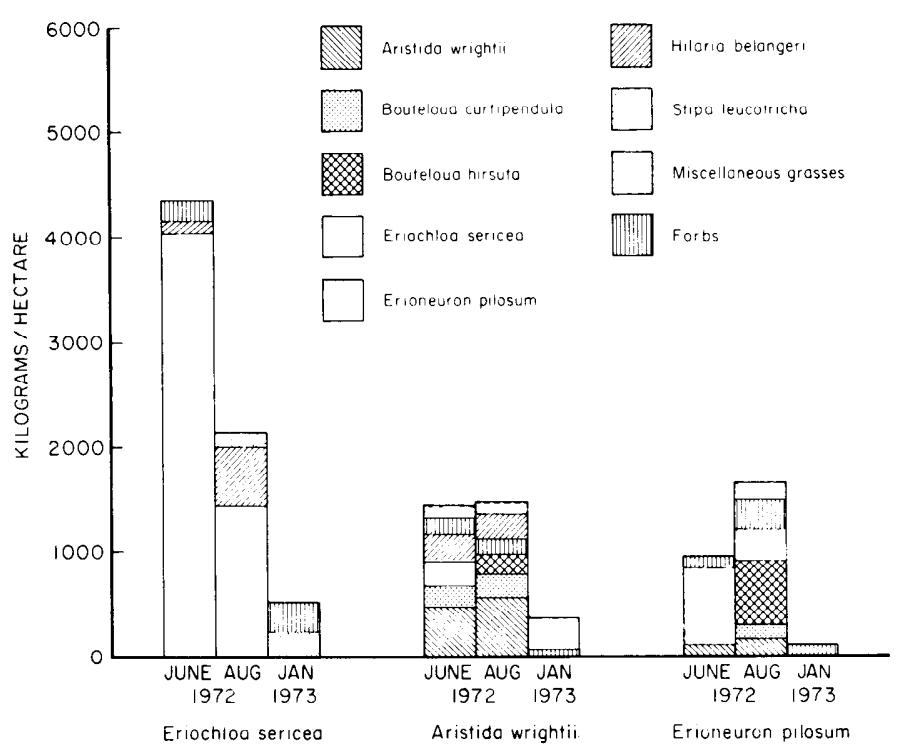

Fig. 3. Green herbage production by species for 3 communities at 3 times during 1972-73 on the Sonora Research Station.

2). Total dead material declined from a high in early summer in all instances with the exception of the hairy tridens stand where the maximum occurred at the late summer clipping. This increase was apparently due to the extensive die-back of hairy tridens prior to the sampling date.

\section{Long-term Vegetation Trends}

Data from 5 years were analyzed to reveal vegetation trends (Table 3, Fig. 4). Total basal diameter for the 5 years was 342 , 44, 200, 124, and $198 \mathrm{~cm} / \mathrm{m}^{2}$ for 1948 through 1968, respectively. The long, severe drought of the early 1950's is reflected by reduction to $44 \mathrm{~cm} / \mathrm{m}^{2}$ for all species in 1953 followed by a rapid recovery once precipitation returned to average or above (Fig. 4).

Common curlymesquite showed a close relationship between annual precipitation and basal diameter (Fig. 4). It made up 78\% of the cover in 1948 but dropped to approximately $50 \%$ thereafter. Merrill (1959) showed that over a 14-year period light grazing and no grazing tended to reduce, although not significantly, the amount of common curlymesquite compared to the amount under moderate and

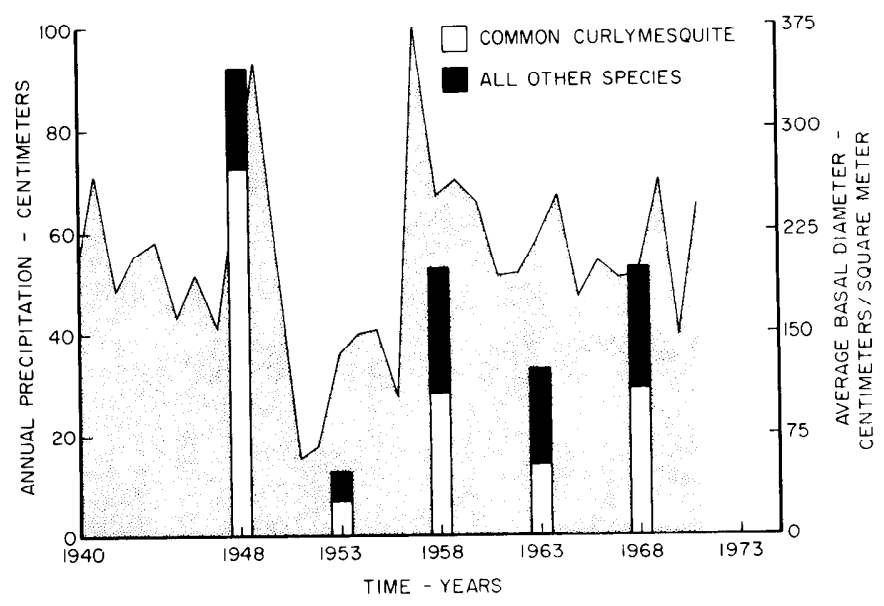

Fig. 4. Total annual precipitation (stippled) at Sonora, Tex., total basal diameter and curlymesquite basal diameter for 5 years on the Sonora Research Station. 
Table 3. Average basal diameter $\left(\mathrm{cm} / \mathrm{m}^{2}\right)$ and relative dominance $(\%)$ for 14 species at 5 dates on the Sonora Research Station.

\begin{tabular}{|c|c|c|c|c|c|c|c|c|c|c|}
\hline \multirow[b]{2}{*}{ Species } & \multicolumn{2}{|c|}{ Dec. 1948} & \multicolumn{2}{|c|}{ Dec. 1953} & \multicolumn{2}{|c|}{ Nov. 1958} & \multicolumn{2}{|c|}{ Dec. 1963} & \multicolumn{2}{|c|}{ Apr. 1968} \\
\hline & Dia. & R.D. & Dia. & R.D. & Dia. & R.D. & Dia. & R.D. & Dia. & R.D. \\
\hline Wright threeawn & 25 & 6 & 2 & 5 & 5 & 2 & 3 & 2 & 7 & 4 \\
\hline Cane bluestem & 1 & 1 & 1 & 2 & 4 & 2 & 5 & 4 & 5 & 3 \\
\hline Sideoats grama & 4 & 1 & 1 & 2 & 1 & 1 & 11 & 9 & 19 & 9 \\
\hline Hairy grama & 3 & 1 & 1 & 2 & 3 & 2 & 4 & 3 & 4 & 2 \\
\hline Rcd grama & 8 & 2 & 1 & 2 & 3 & 2 & 2 & 2 & 2 & 1 \\
\hline Texas cupgrass & - & - & - & - & 3 & 2 & 10 & 8 & 14 & 7 \\
\hline Hairy tridens & 19 & 5 & 3 & 7 & 43 & 22 & 11 & 9 & 13 & 7 \\
\hline Common curlymesquite & 270 & 78 & 24 & 55 & 105 & 53 & 56 & 45 & 106 & 54 \\
\hline Fall witchgrass & 5 & 1 & 3 & 7 & 23 & 12 & 7 & 6 & 11 & 6 \\
\hline Bush muhly & 1 & 1 & - & - & - & - & - & - & - & - \\
\hline Halls panicum & 1 & 1 & 4 & 9 & 4 & 2 & 4 & 3 & 3 & 2 \\
\hline Vine mesquite & 1 & 1 & 1 & 2 & 1 & 1 & - & - & - & - \\
\hline Texas wintergrass & 3 & 1 & 1 & 3 & 1 & 1 & 1 & 1 & 1 & 1 \\
\hline Orange zexmenia & - & - & 1 & 2 & 2 & 1 & 8 & 6 & 2 & 1 \\
\hline Others & 1 & 1 & 1 & 2 & 2 & 1 & 2 & 2 & 11 & 6 \\
\hline Total & 342 & 100 & 44 & 100 & 200 & 100 & 124 & 100 & 198 & 100 \\
\hline
\end{tabular}

heavy grazing on the Sonora Research Station. Current information showed that after 25 years of no grazing the species had levelled off at about $50 \%$ of the composition. Thus, it made an initial adjustment to release from grazing and now fluctuates primarily in relation to precipitation variation. A similar result was documented by Thomas and Young (1954) for buffalograss and common curlymesquite near Barnhart, Tex.

Although never as abundant as common curlymesquite, Wright threeawn exhibited a similar response to release from grazing and precipitation. Hairy tridens contributed 5 to $10 \%$ of the composition in all years, except 1958, when it increased to $22 \%$. This was probably a result of its ability to make a quick response in the relatively open community following the drought. Two grasses, bush muhly (Muhlenbergia porteri) and vine-mesquite (Panicum obtusum), have disappeared from the flora, while Texas cupgrass did not appear until 1958 but has since continually increased. Hairy grama, red grama (Bouteloua trifida), and Texas wintergrass have always been recorded but none has ever contributed more than $3 \%$ of the total basal diameter. The exclosure presently supports a number of forbs that are uncommon on even moderately grazed areas and were not present in early samples. Included are orange zexmenia, awnless bushsunflower, and Engelmanndaisy (Engelmannia pinnatifida).

Cane bluestem, sideoats grama, and fall witchgrass (Leptoloma cognatum) have all increased through time. Cessation of grazing appears to have a favorable impact on their abundance. Some species such as cane bluestem, sideoats grama, green sprangletop (Leptochloa dubia), and little bluestem (Schizachyrium scoparium) might be expected to be more abundant after 25 years of protection. Limited seed source may explain their rather low values. It is possible these species never, even prior to overstocking of these ranges, contributed a significant amount to the vegetation, although observations on adjacent deferred rotation pastures indicate that sideoats grama and cane bluestem have become more abundant under this grazing regime than in the exclosure.

Evidence indicates lower woody plant abundance prior to settlement (Havard, 1885; Bray, 1906). Overgrazing and removal of fire are commonly cited as causes for increase of species such as honey mesquite (Prosopis glandulosa var. glandulosa), junipers (Juniperus spp.), and Vasey shin oak (Quercus pungens var. vaseyana) across the Edwards Plateau
(Buechner, 1944; Huss, 1954; Vallentine, 1960). From this study it appears that once established, woody species tend to increase to a point of stabilization under complete protection. Aerial photographs suggest little if any change in woody plant cover since 1955. Similar results were obtained for an exclosure near Spur, Tex., ' and it was suggested that competition from perennial herbaceous vegetation slowed the rate of invasion of woody species (Scifres et al., 1971). However, in some areas woody plants increase in the presence of a good grass cover if fire is excluded (Johnsen, 1962; Cable and Martin, 1973).

Although limitations exist in the use of exclosures, they neverthcless offer a frame of reference for comparative purposes. If their limitations are understood and conditions of the exclosure are defined, they can serve as useful objects of study. It is agreed that they may not simulate the potential or the most desirable vegetation for a particular time, place, or purpose.

Examination of the data and the protected status of the exclosure may tempt usage of the term climax. Climax implies a natural stimulation while exclosures may be considered unnatural (Beetle, 1974). Most North American rangeland vegetation evolved under use by grazing animals (Larson, 1940; Beetle, 1974) with some sort of seasonal or annual grazing deferment; only with the appearance of European man was confined, continuous overgrazing practiced. Fire is considered an integral natural component of this ecosystem (Bray, 1906; Daubenmire, 1968; Wright, 1974) and periodic macroclimatic fluctuations have occurred (Borchert, 1950; Albertson and Tomanek, 1965). Grazing has been suppressed on the study area for 25 years and fire for a much longer time. One major drought has occurred since establishment of the exclosure (Fig. 4). It seems probable that after each round of disturbance, natural or manmade, community development tends toward a relatively stable community, but fidelity of reestablishment of the same community composition on the same site after each disturbance is suggested to be relatively low. Future comparison of this exclosure with adjacent pastures grazed by varying combinations and intensities of animals and with different grazing systems may resolve some of these questions of community stability.

\section{Literature Cited}

Albertson, F. W. 1937. Ecology of mixed prairie in west central Kansas. 
Ecol. Monogr. 7:481-547.

Albertson, F. W., and G. W. Tomanek. 1965. Vegetation changes during a 30-year period on grassland communities near Hays, Kansas. Ecology 46:714-720.

Beals, E. 1960. Forest bird communities in the Apostle Island, Wisconsin. Wilson Bull. 72:156-181.

Beetle, A. A. 1974. The zootic disclimax concept. J. Range Manage. 27:30-32.

Bentley, H. L. 1898. Cattle ranges in the Southwest: a history of the exhaustion of the pasturage and suggestions for its restorage. U.S. Dep. Agr. Farmers Bull. 72.32 p.

Borchert, J. R. 1950. The climate of the central North American grassland. Ann. Ass. Amer. Geog. 11:1-39.

Buoyoucos, G. J. 1962. Hydrometer method improved for making particle size analysis of soils. Agron. J. 54:464-465.

Bray, W. L. 1906. Distribution and adaptation of the vegetation of Texas. Univ. Texas Bull. 82. 181 p.

Bray, J. R., and J. T. Curtis. 1957. An ordination of the upland forest communities of southern Wisconsin. Ecol. Monogr. 27:325-349.

Buechner, H. K. 1944. The range vegetation of Kerr County, Texas, in relation to livestock and white-tailed deer. Amer. Midl. Natur. 31:696-743.

Cable, D. R., and S. C. Martin. 1973. Invasion of semi-desert grassland by velvet mesquite and associated vegetation changes. Ariz. Acad. Sci. 8:127-134.

Clements, F. E. 1934. The relict method in dynamic ecology. J. Ecol. 22:39-68.

Daubenmire, R. 1959. A canopy-coverage method of vegetational analysis. Northwest Sci. 33:43-64.

Daubenmire, R. 1968. Ecology of fire in grasslands. Adv. Ecol. Res. $5: 209-266$.

Dix, R. L. 1960. The effect of burning on the mulch structure and species composition of grasslands in western North Dakota. Ecology $41: 49-56$.

Dyksterhuis, E. J. 1958. Ecological principles in range evaluation. Bot. Rev. 24:253-272.

Godfrey, C. L., C. R. Carter, and G. S. McKee. 1970. Resource areas of Texas. Tex. Agr. Ext. Serv., Tex. Agr. Exp. Sta. Bull. 1070. 24 p.

Gould, F. W. 1969. Texas plants: A checklist and ecological summary. Texas Agr. Exp. Sta. MP-585 revised. 121 p.

Havard, V. 1885. Report on the flora of western and southern Texas. Proc. U.S. Nat's. Museum 8:449-533.
Hulett, G. K., G. L. Van Amburg, and G. W. Tomanek. 1969. Soil depth-vegetation relationships on a shallow loamy range site in western Kansas. J. Range Manage. 22:196-199.

Huss, D. L. 1954. Factors influencing plant succession following fire in ashe juniper woodland types in Real County, Texas. PhD dissertation. Texas A\&M Univ. College Station.

Johnsen, T. N. 1962. One-seeded juniper invasion of northern Arizona grassland. Ecology 21:113-121.

Larson, F. 1940. The role of the bison in maintaining the short grass plains. Ecology 21:113-121.

Larson, F., and W. Whitman. 1942. A comparison of used and unused grassland mesas in the Badlands of South Dakota. Ecology 23:438-445.

Mason, L. R. 1970. A look at range relicts. J. Soil and Water Cons. 25:18-19.

Merrill, L. B. 1959. Relationship of germination and growth of curlymesquite (Hilaria belangeri (Steud.) Nash) to management practices and natural environment. PhD dissertation. Texas A\&M Univ. College Station.

Nicholson, R. A., and G. K. Hulett. 1969. Remnant grassland vegetation in the central Great Plains of North America. J. Ecol. 57:599-612.

Scifres, C. J., J. H. Brock, and R. R. Hahn. 1971. Influence of secondary succession on honey mesquite invasion in North Texas. J. Range Manage. 24:206-210.

Soil Conservation Service. 1968. Soil Survey Sutton County, Texas. U.S. Dep. Agr., Soil Cons. Serv. 33 p.

Tharp, B. C. 1939. The vegetation of Texas. Tex. Acad. Sci. Publ. Nat. Hist., Non-tech. Ser. 1.74 p.

Thomas, G. W., and V. A. Young. 1954. Relation of soils, rainfall and grazing management to vegetation, western Edwards Plateau of Texas. Tex. Agr. Exp. Sta. Bull. 786. 22 p.

U. S. Dep. Commerce. 1926-1968. Climatological data, Texas. Weather Bureau. Annual summaries.

Vallentine, J. F. 1960. Life oak and shin oak as desirable plants on Edwards Plateau ranges. Ecology 41:545-548.

Wright, H. A. 1974. Range burning. J. Range Manage. 27:5-11.

Youngblood, B., and A. B. Cox. 1922. An economic study of a typical ranching area on the Edwards Plateau of Texas. Tex. Agr. Exp. Sta. Bull. 297. 437 p. 